\title{
The role of energy and fluid imbalance in weight changes found during field work in Antarctica
}

\author{
BY J. J. BOYD* \\ Australian National Antarctic Research Expeditions (1970), \\ Davis, Antarctica
}

(Received I4 Fune I974-Accepted Io March 1975)

\begin{abstract}
I. The effect on body-weight of field work in Antarctica when travelling by mechanical transport has been studied.

2. A steady loss of weight (mean $6.2 \mathrm{~kg}$ ) was found in the field, and there was a slow gain on return to less arduous conditions.

3. Changes in skinfold thickness and hip girth suggested that the loss of weight was due to an energy deficit, and the gain was due to an excess of energy.

4. However, although weight was being lost the energy balance was calculated to be positive. This was probably because the expenditure was underestimated as the result of a failure to take into account: (a) the weight and restriction of heavy clothing, $(b)$ the highprotein diet, $(c)$ the difficulty imposed by the terrain, $(d)$ the intensity of the subjects' response to the cold.

5. Daily weight changes were significantly related to climatic conditions.

6. Daily weight changes were significantly related to fluid intakes, but it was not possible to assess with certainty the contribution made by dehydration to the recorded weight loss.

7. Daily fluctuations in weight were greater than those previously found under more standard conditions.
\end{abstract}

Loss of body-weight by men dog-sledging in polar regions has been found on many occasions. Ekelöf (1904) reported losses as high as $7 \mathrm{~kg}$, but more recently Massey (1956), Lewis, Masterton \& Rosenbaum (1960), Wilson (1960), Orr (1965) and Budd ( 1966 ) reported losses of up to $8 \mathrm{~kg}$. Most of these authors also reported that weight is rapidly regained after return to the home station: as much as $3 \mathrm{~kg}$ in the first $24 \mathrm{~h}$.

The cause of this loss and subsequent regain in weight has not been established. Energy imbalance seemed to be primarily responsible in the examples quoted by Edholm (1964) and Orr (1965). However, fluid imbalance was considered important by Massey (1956), and was believed to be the main factor by Lewis et al. (1960) and Wilson (1960). The pattern of this weight change might help to identify its cause. Gradual and progressive change would more likely reflect energy imbalance, while rapid change to subsequently stable levels would reflect fluid imbalance.

On many expeditions mechanical transport is now replacing dog-sledging. It would be expected that the energy expenditure using mechanical transport would be less than that associated with dog-sledging (an activity involving long periods of running and pushing heavy sleds). However, Hicks (ig66) reported losses of up to $6 \mathrm{~kg}$ occurring in field parties driving enclosed, heated tractors. As decreases in skinfold thickness also occurred, he concluded that energy imbalance was an important cause.

* Present address: 2 Lawrence Street, West Ryde, New South Wales 21 I4, Australia. 
The principal aim of the present study, undertaken in Antarctica during a field journey using mechanical transport, was to determine the magnitude and pattern of any weight changes found. Further aims were to assess the respective contributions of energy and fluid imbalance to any change, and to determine whether there was a relationship between the changes of weight and those of the thermal environment.

\section{METHODS}

The field journey by members of the Australian National Antarctic Research Expeditions (ANARE) occupied $42 \mathrm{~d}$ between October and December 1970. The route was inland from Davis $\left(68^{\circ} 38^{\prime} \mathrm{S}, 77^{\circ} 5^{\prime} \mathrm{E}\right.$ ), an Antarctic Division Station on the coast of Antarctica. A total distance of $900 \mathrm{~km}$ was travelled, and a maximum altitude of $2000 \mathrm{~m}$ was reached on the continental ice-cap.

\section{Field conditions}

Mode of transport. Small, open, motorized toboggans were used to haul sleds carrying the supplies and equipment. While driving the toboggans the riders spent long periods (occasionally up to $24 \mathrm{~h}$ ) inactive and exposed to the weather. This often resulted in prolonged cold discomfort and shivering, and all members of the party suffered minor frostbite of the face and extremities.

Clothing. A large amount of clothing was worn. The basic assembly comprised five layers on the upper trunk, three on the lower trunk, five on the feet, four on the hands, and two on the head. When outdoors, a down-filled anorak and a suit of doublethickness windproof 'ventile' material were worn over this basic assembly. Downfilled trousers were also worn on occasions 'The total weight of the outdoor assembly was I I $\mathrm{kg}$, of which footwear comprised $3 \mathrm{~kg}$.

Shelter. Of the $42 \mathrm{~d}$ spent in the field, the first $3 \mathrm{~d}$ and last $6 \mathrm{~d}$ were spent at an observation hut $32 \mathrm{~km}$ from Davis, but for the remaining $33 \mathrm{~d}$, tents were used. Inside both hut and tents, reasonable thermal comfort was achieved by lying in sleeping bags, or by using a cooking stove for heating. Sleeping bags were of quilted down, used double (one inside the other), and were insulated from the cold floor by foam mattresses. Bad weather prevented travel on $\mathrm{I} 3 \mathrm{~d}$, although other outside work was prevented on I $d$ only. This agrees with the reports of most polar travellers who have reported an average of I 'lie-up day'/3 $\mathrm{d}$.

\section{Subjects}

Observations were made on three members of the field party. A fourth subject, who remained at Davis throughout the period of the field journey, served as a control. The physical characteristics of the subjects are given in Table r. All subjects had lived at Davis for 8 months before the field journey started. 
Table I. Physical characteristics at the beginning of the study, for the three field-journey subjects, members of the Australian National Antarctic Research Expeditions (1970), and a fourth subject (subject $Z$ ), also a member of the Expeditions, who remained at Davis, an Antarctic Division Station on the coast of Antarctica: all had lived at Davis for 8 months before the study

$\begin{array}{cccc}\text { Subject } & \text { Age (years) } & \text { Height }(\mathrm{m}) & \text { Weight }(\mathrm{kg}) \\ \text { W } & \mathbf{2 8} & \mathbf{I} \cdot 88 & 88 \cdot 5 \\ \text { B } & 24 & \mathrm{I} \cdot 78 & 72 \cdot \mathrm{I} \\ \text { S } & 37 & \mathrm{I} \cdot \mathbf{7 2} & 67 \cdot 4 \\ \text { Z } & \mathbf{2 8} & \mathrm{I} \cdot 86 & 90 \cdot 7\end{array}$

Daily measurements

Daily measurements were made only on the three field subjects. Body-weight was measured daily for $3 \mathrm{~d}$ before departure, for $42 \mathrm{~d}$ in the field, and for $16 \mathrm{~d}$ after their return. Energy intake and expenditure were assessed for the $33 \mathrm{~d}$ working from tents, and fluid intake was measured for all $42 \mathrm{~d}$ in the field.

Body-weight. Clinical Scales (Salter type 209; George Salter Pty Ltd, I6 Grosvenor St, Abbotsford 3067, Australia) were used for weighing the subjects. They were calibrated with test weights and found to be sufficiently accurate to allow recording to $0.1 \mathrm{~kg}$. A standard $50 \mathrm{~kg}$ weight was used periodically in the field to check the calibration, and no error due to temperature or altitude was found. Zero adjustment was made carefully before each weighing procedure. Each subject was weighed in a pyjama suit in the morning after micturition. Regular checks showed that there was no variation in the weight of this light clothing, therefore it was subtracted from each daily recorded value to give a 'nude' body-weight.

Energy intake. During the $33 \mathrm{~d}$ working from tents, all food eaten was obtained from standard ANARE field ration packs, which have been designed to provide 19.7 MJ (4700 kcal) and $193 \mathrm{~g}$ protein/d (Australian National Antarctic Research Expeditions, 1969). Healthy appetites ensured equal distribution of the rations, and on most days the full ration was eaten. However, on $9 \mathrm{~d}$ the time for food preparation was limited, and only half the normal ration was eaten. These uneaten rations were not eaten on subsequent days. During the $9 \mathrm{~d}$ spent at the observation hut unlimited food supply precluded any record of energy intake, but all subjects agreed their intake greatly exceeded that when working from tents.

Energy expenditure. Detailed records allowed determination of the time (min) spent in different activities each day. Each activity was then allocated to one of the sixteen categories shown in Table 2. The energy cost for each of these categories was derived from standard estimates (Consolazio, Johnson \& Pecora, 1963; Durnin \& Passmore, 1967). The energy costs were corrected for body-weight (Malhotra, Ramaswamy \& Ray, I962), using a ratio correction with a numerator of $73 \mathrm{~kg}$ (the mean weight for the field period). No correction was made for clothing, or for the specific dynamic action of the high protein intake.

Sleeping in field conditions has an energy cost similar to the basal metabolic rate (Rennie, 1958), and a mean value of $5.0 \mathrm{~kJ}(\mathrm{r} \cdot 2 \mathrm{kcal}) / \mathrm{min}$ was adopted (Durnin \& 
Table 2. Standard activities undertaken by members of the Australian National Antarctic Research Expeditions (1970) and their estimated energy cost

$\quad$ Activity
Sleeping
Lying
Sitting
Standing
Light manual work
Driving toboggan
Dressing
Placing trail markers
Meteorological observations
Refuelling
Walking
En- and de-camping
Loading sleds
Shovelling snow
Pushing sled
Walking uphill

Energy cost

(kJ (kcal)/min)

$$
\begin{aligned}
& 5.0(1.2) \\
& 6.3(1.5) \\
& 10.9(2.6) \\
& 11.7(2.8) \\
& 13.4(3.2) \\
& 15.1(3.6) \\
& 17.6(4.2) \\
& 18.8(4.5) \\
& 19.2(4.6) \\
& 19.7(4.7) \\
& 31.4(7.5) \\
& 33.5(8.0) \\
& 33.5(8.0) \\
& 41.8(10.0) \\
& 50.2(12.0) \\
& 50.2(12.0)
\end{aligned}
$$

Passmore, 1967). Sitting involved considerable movement while doing chores inside the tent, and a value of $10.9 \mathrm{~kJ}(2.6 \mathrm{kcal}) / \mathrm{min}$, higher than previously reported, was used. Standing was usually accompanied by movements of arms when directing glaciological survey procedures, and the value obtained for conducting an orchestra $(\mathrm{II} \cdot 7 \mathrm{~kJ}(2.8 \mathrm{kcal}) / \mathrm{min})$ (Durnin \& Passmore, 1967) was adopted. Driving a motorized toboggan was likened to driving a motorcycle, which had been evaluated previously by Consolazio et al. (1963) ( $15 \cdot \mathrm{I} \mathrm{kJ}(3.6 \mathrm{kcal}) / \mathrm{min})$. Making meteorological observations involved preparation, leaving the tent, and some walking in a strong wind and on uneven ground. Walking across hard-packed snow with considerable 'sastrugi' ridging was considered to be similar to walking across a ploughed field, and was given a value of $3 x^{\circ} 4 \mathrm{~kJ}(7.5 \mathrm{kcal} / \mathrm{min})$ (Durnin \& Passmore, 1967).

Fluid intake. Water for drinking and cooking was obtained by melting snow, and the intake was recorded each day.

\section{Other measurements}

Measurements were made on the control subject and the three members of the field party on only four occasions: twice ( 47 and $3 \mathrm{~d}$ ) before departure, once $34 \mathrm{~d}$ after the field party had left ( $8 \mathrm{~d}$ before it returned) that is, in the field, and once $16 \mathrm{~d}$ after it had returned to Davis.

Body-zweight. Body-weight was measured for the three field subjects as part of their daily routine. The control subject at Davis was weighed only on the four occasions, nude, using a beam balance (accurate to $0.0 \mathrm{rg}$ at $75 \mathrm{~kg}$ ).

Skinfold thickness. Harpenden Calipers (British Indicators Ltd, Hatfield Road, St Albans, Herts., England) were used to measure skinfold thickness at the left triceps and subscapular sites (Edwards, Hammond, Healy, Tanner \& Whitehouse, 1955).

Hip girth. Hip girth was measured at the level of the symphysis pubis, anteriorly, 


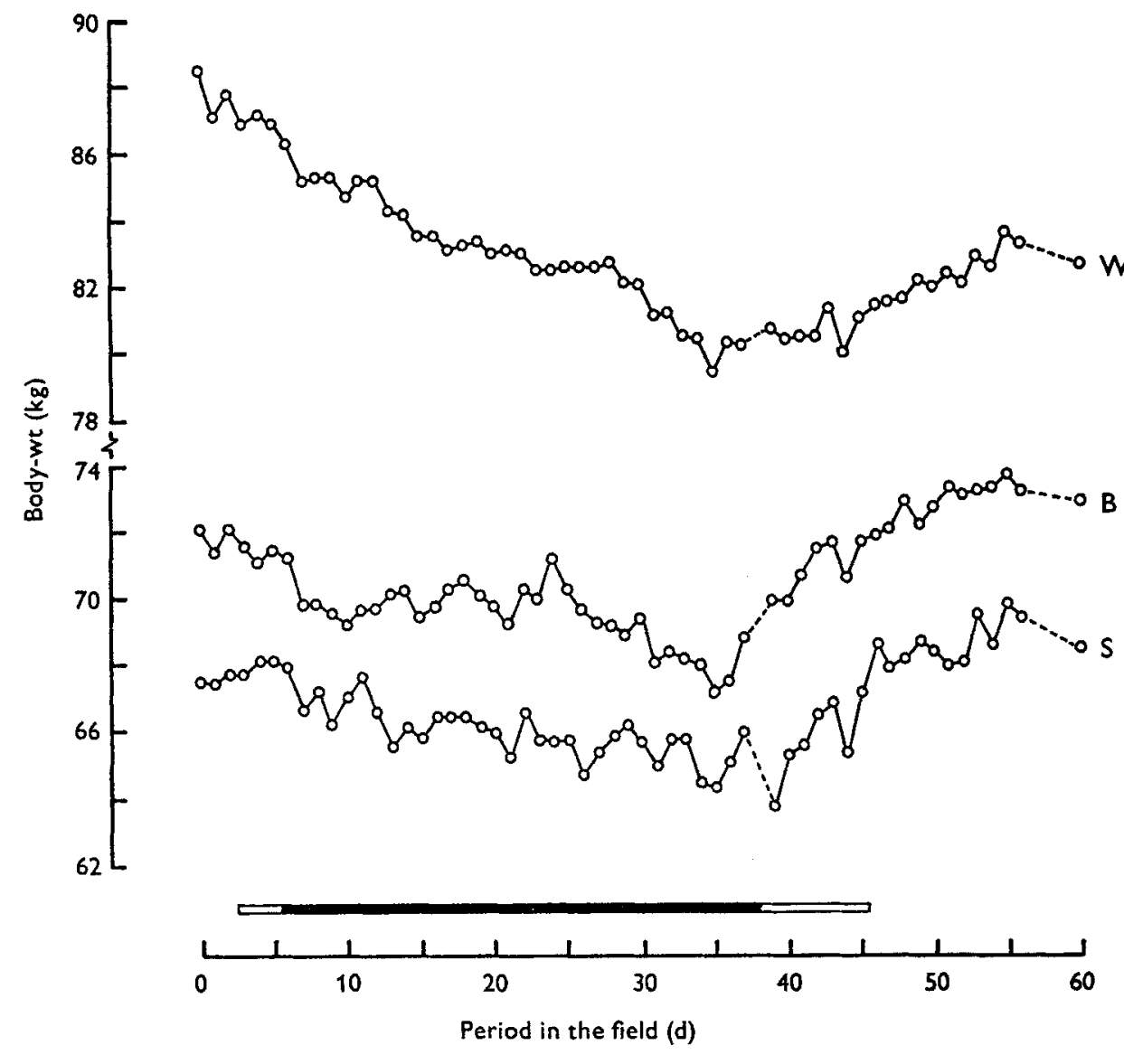

Fig. I. Daily body-weights for three members of the Australian National Antarctic Research Expeditions (1970) (subjects W, B and S) before, during and after a field journey lasting $42 \mathrm{~d}$. - - D Days when no observations were made. $\square$, Time spent in the field in the hut; घ, time spent in the field in tents.

and at the maximal protrusion of the gluteal musculature, posteriorly (Wilmore \& Behnke, 1969). The measurement was made to the nearest $\mathrm{mm}$ using a flexible steel tape, with the subject standing relaxed.

Arm circumference. The circumference at the midpoint of the left upper arm was measured using a flexible steel tape, with the arm hanging by the side and the forearm pronated.

Urine output. Urine was collected for the members of the field party and the control subject for $24 \mathrm{~h}$ before the four measurements of body-weight, skinfold thickness, hip girth and arm circumference were made, and the volume was recorded.

\section{Climatic measurements}

These were made in the field and at Davis before departure and after return.

Outdoors. Regular measurements of air temperature, windspeed and relative humidity were made whenever working outdoors. Values for windchill were calculated 

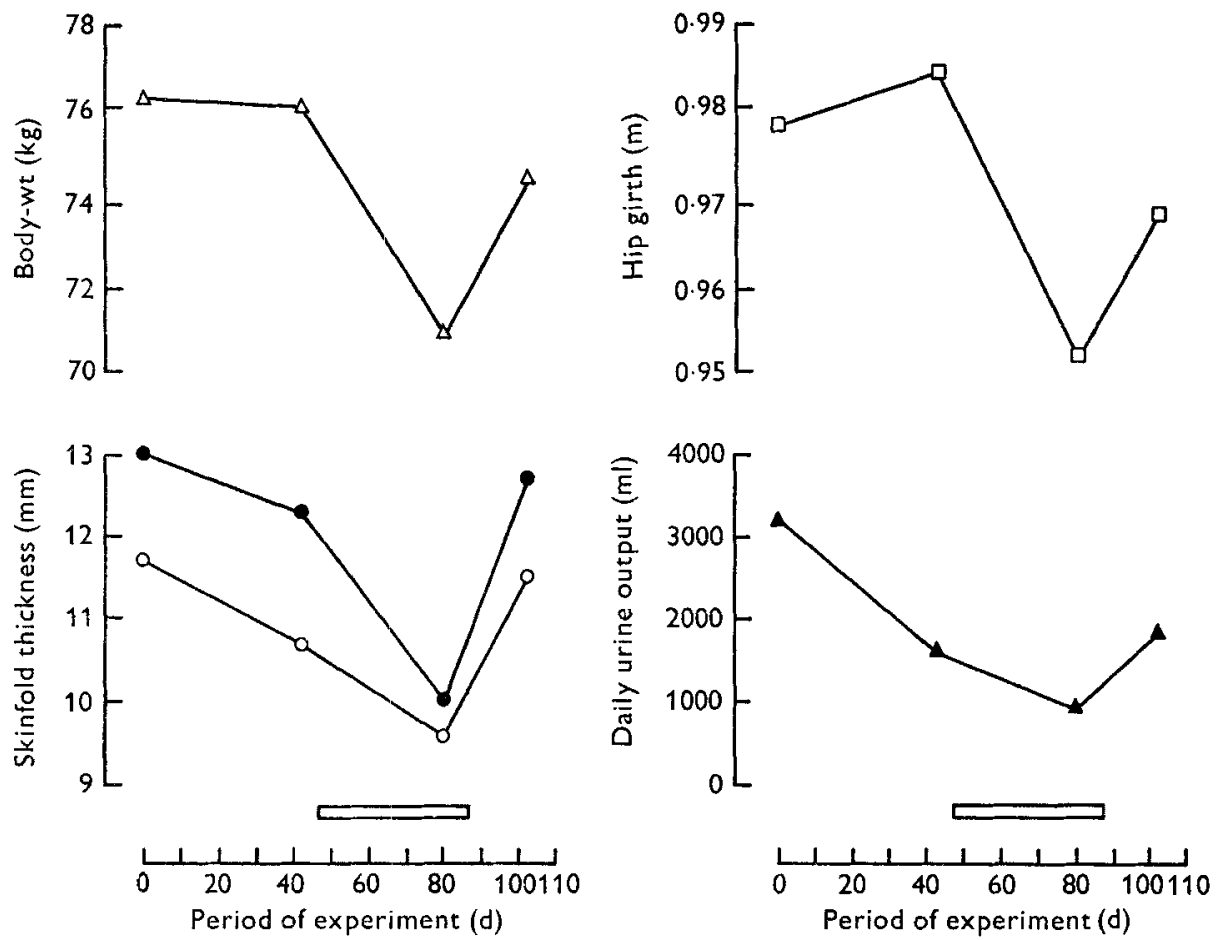

Fig. 2. Skinfold thickness (, , subscapular; $\bigcirc$, triceps), hip girth and daily urine output for three members of the Australian National Antarctic Research Expeditions (1970) twice before departure, once in the field and once after return from a field journey lasting $42 \mathrm{~d}$, and bodyweight on the same days. $\square$, Time spent in the field.

from dry-bulb thermometer temperatures and windspeeds (Siple \& Passel, 1945). The importance of radiation in heat transfer in Antarctica has been reported by Chrenko \& Pugh (1962), and in the present study, globe-thermometer temperatures at noon (Vernon, 1932; Bedford, 1964) were measured whenever the party was working outside at noon.

Indoors. Air and globe-thermometer temperatures (Table 3), and relative humidity were measured while inside tents in the field and in living quarters at Davis. Air movement was also measured in the living quarters at Davis.

\section{Statistical treatment}

Daily body-weight changes were examined for correlation with corresponding energy intake, energy expenditure, energy balance, fluid intake, and mean outdoor air temperature, windspeed and windchill.

\section{RESULTS}

The three subjects in the field party lost $9 \cdot 2,5^{\circ} 0$ and $4.4 \mathrm{~kg}$ weight in the field (while in tents), and they regained $4 \cdot \mathrm{I}, 6 \cdot 5$ and $6 \cdot 0 \mathrm{~kg}$ respectively, after return to less arduous conditions at the hut and at Davis. Over the corresponding periods 
Table 3. Mean climatic conditions outdoors in Antarctica, in the field and at Davis, an Antarctic Division Station on the coast of Antarctica, before and after a field journey lasting $42 d$, during the Australian National Antarctic Research Expeditions (1970)

Mean time spent outdoors $(\mathrm{h} / \mathrm{d})$

Air temperature $\left(^{\circ}\right)$

Windspeed $(\mathrm{m} / \mathrm{s})$

Relative humidity (\%)

Windchill*

Globe-thermometer increment $+\left({ }^{\circ}\right)$

$\begin{array}{cc}\text { Davis, before } & \text { In the } \\ \text { field journey } & \text { field } \\ 6 & 5 \cdot 9 \\ -8 \cdot 9 & -13 \cdot 8 \\ 8 & 12 \\ 56 & 62 \\ 1000 & 1250 \\ 14.7 & 7 \cdot 3\end{array}$

Davis, after field journey

* 'Windchill' which is used exclusively in relation to cold environments, is defined as that part of the total cooling that is due primarily to the wind action.

+ Globe-thermometer increments were obtained by subtracting the air temperatures from the globethermometer temperatures.

Table 4. Mean climatic conditions indoors in Antarctica, in the field and at Davis, an Antarctic Division Station on the coast of Antarctica, before and after a field journey lasting 42 d, during the Australian National Antarctic Research Expeditions (1970)

Air temperature $\left(^{\circ}\right)$

Windspeed $(\mathrm{m} / \mathrm{s})$

Relative humidity (\%)

Globe-thermometer increment* $\left(^{\circ}\right)$

$\begin{array}{ccc}\begin{array}{c}\text { Davis, before } \\ \text { field journey }\end{array} & \begin{array}{c}\text { In the } \\ \text { field }\end{array} & \begin{array}{c}\text { Davis, after } \\ \text { field journey }\end{array} \\ 18.0 & -7.4+ & 20.2 \\ 0.05 & - & 0.05 \\ 45 & 73 \ddagger & 41 \\ 3.2 & - & 3.9\end{array}$

* Globe-thermometer increments were obtained by subtracting the air temperatures from the globethermometer temperatures.

$\dagger$ Air temperature fluctuated between $-2 I$ and $2^{\circ}$. There were peaks which corresponded to periods of cooking or using the cooking stove for heating, and there was a general reduction at about midnight and the early morning.

I Humidity fluctuated between 45 and $90 \%$. There were peaks which corresponded to periods of cooking and reductions in air temperature.

subject $\mathrm{Z}$, who remained at Davis, gained 0.5 and $0 . \mathrm{I} \mathrm{kg}$ respectively. The changes in body-weights are shown in Fig. I.

Apart from the larger over-all changes there was a minor variation in body-weight from day to day. Linear regression lines were fitted separately for each subject for the periods when weight was lost and regained. The mean coefficients of variation about the regression lines were $\mathrm{I} \cdot 0$ and 0.9 respectively.

The results in Fig. 2 indicated that the changes in skinfold thickness, hip girth and arm circumference reflected the main changes in body-weight. The daily changes in weight, however, were not significantly correlated with corresponding energy intakes, expenditures or balances. The mean energy intake while living in tents was $16.9 \mathrm{MJ}$ $(4 \circ 5 \circ \mathrm{kcal}) / \mathrm{d}$, and the mean energy expenditure was estimated at $14.6 \mathrm{MJ}(3500$ $\mathrm{kcal}) / \mathrm{d}$. While the body-weight was decreasing, therefore, the balance suggested there was a net energy excess of $2 \cdot 3 \mathrm{MJ}\left(55^{\circ} \mathrm{kcal}\right) / \mathrm{d}$.

Daily changes in body-weight were found to be correlated with corresponding fluid intakes $(P<0.05)$. The few measurements that were made of the $24 \mathrm{~h}$ urine 
Table 5. Air temperature and globe-thermometer increments at different heights inside a tent,* while using a cooking stove for heating, during a field journey lasting $42 d$, during the Australian National Antarctic Research Expeditions (1970)

(Most of the time in a tent is spent either lying at floor level or sitting (head level being approximately $\mathrm{r} \cdot 5 \mathrm{~m}$ above floor))

Height above
floor $(\mathrm{m})$
0.15
1.00
1.50

Air temperature
$\left({ }^{\circ}\right)$
4.3
15.6
$28 \cdot 3$

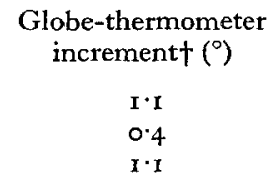

* Outdoor conditions: air temperature $-15 \cdot 7^{\circ}$, windspeed $10 \mathrm{~m} / \mathrm{s}$.

$\uparrow$ Globe-thermometer increments were obtained by subtracting the air temperatures from the globethermometer temperatures.

volume (also shown in Fig. 2) indicated that there was a small decrease in the field, but the large decrease before departure suggested that little could be made of these measurements. The respiratory losses may have been high, but the mean fluid intake measurement in the field was $2 \cdot \mathrm{I} 1 / \mathrm{d}$, to which must be added nearly $500 \mathrm{ml}$ for the water of oxidation.

Daily weight changes were found to be correlated $(P<0.05)$ with corresponding mean air temperatures, windspeeds and windchills, the weight loss increased as the air temperature decreased and windspeed and windchill increased.

The mean climatic conditions outdoors are given in Table 3 , and the conditions indoors are given in Tables 4 and 5 .

\section{DISCUSSION}

It would appear that losses of weight for men using mechanical transport in the field in Antarctica are of the same order as those previously found for men using dog-sledges. The subsequent gains on return to the home station are also of similar magnitude. This confirms the findings of Hicks ( 1966 ).

The changes in weight for members of the field party (a mean loss of $6 \cdot 2 \mathrm{~kg}$ followed by a mean gain of $5.5 \mathrm{~kg}$ ) were much greater than those for the control subject (an increase of $0.5 \mathrm{~kg}$ followed by a further increase of $0^{\circ} \mathrm{I} \mathrm{kg}$ ) and would be highly significant changes in weight for the 'normal' population described by Khosla 8 Billewicz (1964). Using their 'scheme I' a change of $0.4 \mathrm{~kg}$ would be significant $(P=0.05)$.

The loss and subsequent regain of body-weight were due, at least in part, to a depletion and replacement of body fat, as indicated by the changes in skinfold thickness, hip girth (Wilmore \& Behnke, I969) and arm circumference. The depletion and replacement of body fat must have been due to a deficiency and excess of energy respectively. The gradual changes of weight also suggested that an energy imbalance was responsible, rather than a change in hydration. A low correlation between daily energy balances and body-weights was found previously by Edholm, Adam, Healy, Wolff, Goldsmith \& Best (I970). 
However, while fat and weight were being lost the calculated energy balance was positive. Possibly the use of standard energy expenditure estimates for Antarctic field conditions is inappropriate. These do not allow for the weight and restriction of heavy polar clothing, which has been demonstrated to be significant (Welch, Levy, Consolazio, Buskirk \& Dee, 1957), or the specific dynamic action of a high-protein diet (Brown \& Brengelmann, 1965). In addition, the high cost of moving over difficult terrain and the behavioural adjustments to a high rate of heat loss (Brotherhood, 1973) may also have been underestimated.

The use of open, motorized transport in this study produced long periods of exposure to the weather while the subjects were inactive, and they were frequently cold and often shivering. This thermogenic response to cold exposure may have produced an increase in their energy expenditure (Keatinge, 1969), for which no allowance was made.

The significant daily relationships between body-weights and mean air temperatures, windspeeds and windchills indicate that in fact thermal stress contributed to the changes in weight.

Body-weight may also have been influenced by fluid restrictions, but the I $\mathrm{d}$ urine output measured in the field was about twice the volume found in dehydrated men by McCance, Young \& Black (1944).

However, a similar study, made at Davis in 1963 (Lugg, 1974), showed that hydration must be responsible for rapid gains in weight. Three subjects, after returning from $53 \mathrm{~d}$ dog-sledging in the field, gained $5.5 \mathrm{~kg}$ (of $7.0 \mathrm{~kg}$ lost) within $18 \mathrm{~h}$ of arrival at Davis. Most of the weight regained on return must have been due to fluid replacement. The mean daily fluid intake in the field in that study was estimated at ${ }_{1} \cdot 51$.

It is concluded that mechanical transport does not spare field parties from considerable weight loss, even if the cause has not yet been finally settled.

This study was undertaken while the author was a member of the Antarctic Division, Department of Supply (now Department of Science), Australia. Thanks are due to the staff of the School of Public Health and Tropical Medicine, University of Sydney, especially to Professor R. K. Macpherson and Dr K. E. Hicks, for helpful criticism, to Dr D. J. Lugg, Antarctic Division, Department of Science, Australia, and to Messrs John Stalker, Richard Westwood and Michael Zappert for their patient co-operation as subjects.

\section{REFERENCES}

Australian National Antarctic Research Expeditions (1969). Operations Manual, p. ro2. Australia: Department of Supply.

Bedford, T. (1964). Basic Principles of Ventilation and Heating, and ed., p. 36. London: H. K. Lewis \& Co. Ltd.

Brotherhood, J. R. (1973). In Polar Human Biology, p. I82 [O. G. Edholm and E. K. E. Gunderson, editors]. London: William Heinemann Medical Books Ltd.

Brown, A. C. \& Brengelmann, G. (x965). In Physiology and Biophysics, igth ed., p. ro46 [T. C. Ruch and H. D. Patton, editors]. Philadelphia and London: W. B. Saunders Co.

Budd, G. M. (1966). F. Physiol., Lond. x86, 201.

Chrenko, F. A. \& Pugh, L. G. C. E. (1962). Proc. R. Soc. B r55, 243.

Consolazio, C. F., Johnson, R. E. \& Pecora, L. J. (r963). Physiological Measurements of Metabolic Functions in Man, p. 329. New York, Toronto and London: McGraw-Hill Book Co. 
Durnin, J. V. G. A. \& Passmore, R. (1967). Energy, Work and Leisure. London: William Heinemann Educational Books Ltd.

Edholm, O. G. (1964). In Antarctic Research, p. 5 I [R. Priestley, R. J. Adie and G. de Q. Robin, editors]. London: Butterworths.

Edholm, O. G., Adam, J. M., Healy, M. J. R., Wolff, H. S., Goldsmith, R. \& Best, T. W. (I970). Br. $\mathcal{F}$. Nutr. 24, 1091

Edwards, D. A. W., Hammond, W. H., Healy, M. J., Tanner, J. M. \& Whitehouse, R. H. (I955). Br. F. Nutr. 9, I33.

Ekelöf, E. (1904). F. Hyg., Camb. 4, 5 ז I.

Hicks, K. E. (1966). Med. F. Aust. 1, 86.

Keatinge, W. R. (1969). Survival in Cold Water, p. II. Oxford and Edinburgh: Blackwell Scientific Publications.

Khosla, T. \& Billewicz, W. Z. (1964). Br.f. Nutr. 18, 227.

Lewis, H. E., Masterton, J. P. \& Rosenbaum, S. (1960). Clin. Sci. 19, 55 r.

Lugg, D. J. (I974). Anatomy of a group in Antarctica. MD Thesis, University of Adelaide.

McCance, R. A., Young, W. F. \& Black, D. A. K. (1944). F. Physiol., Lond. 102, 41 5.

Malhotra, M. S., Ramaswamy, S. S. \& Ray, S. N. (1962). F. appl. Physiol. 17, 433.

Massey, P. M. O. (1956). Acclimatization to cold in Antarctica. MD Thesis, Cambridge University.

Orr, N. W. M. (1965). Br. F. Nutr. 19, 79.

Rennie, D. W. (1958). In Cold Injury: Transactions of the Fifth Conference, March 1957, p. 253 [M. I. Ferrer, editor]. New York: Josiah Macy Jr Foundation.

Siple, P. A. \& Passel, C. F. (I945). Proc. Am. phil. Soc. 89, 177.

Vernon, H. M. (1932). F. ind. Hyg. Toxicol. 14, 95.

Welch, B. E., Levy, L. M., Consolazio, C. F., Buskirk, E. R. \& Dee, T. E. (1957). U.S. Army Medical Research and Nutrition Laboratory Report, Denver, no. 202.

Wilmore, J. H. \& Behnke, A. R. (1969). F. appl. Physiol. 27, 25.

Wilson, O. (1960). Br. F. Nutr. 14, 391. 